\title{
Evolution of potential biomarkers of acute muscle injury after physical exercise
}

\author{
Eduardo Ottobelle Chielle ${ }^{\circledR *}$, Lucilene Wildner Granella ${ }^{1}$, Jorlana Stacke Maziero', \\ Tiago Mateus Andrade Vidigal ${ }^{1}$, Bárbara Lidiane Kummer Mallmann ${ }^{1}$, Jaison Karal ${ }^{2}$
}

${ }^{1}$ University of West of Santa Catarina, Department of Life Sciences, Laboratory of Clinical Biochemistry, São Miguel do Oeste, SC, Brazil, ' University of West of Santa Catarina, Department of Life Sciences, Laboratory of Exercise Physiology, São Miguel do Oeste, SC, Brazil

\begin{abstract}
Skeletal muscle injury is a frequent event and diagnosis using the classical blood markers sometimes produces unsatisfactory results. Therefore, objective of the study was to detect new biomarkers in plasma, saliva and urine in response to acute muscle damage induced by physical exercise. A cross-sectional study was conducted with 27 American football players. Before the physical exercises (T0), 60 minutes (T1) and 24 hours (T2) after physical exercise, was determined the clinical, biochemical and molecular parameters, including ADA, TBARS, leukocytes, lymphocytes and comet assay. The serum ADA was significantly higher in $\mathrm{T} 1$ and $\mathrm{T} 2$, in the urine there was a significant increase in $\mathrm{T} 1$, in the saliva there was no significant differences. There was an increase in serum TBARS in T2, saliva and urine in T1. The leukocytes increased in T1 and decreased in T2. Through the comet assay was observed significant DNA damage in T1 and T2. Serum and urinary ADA activity, serum, urinary and salivary TBARS are robust and promising biomarkers of acute muscle injury and that the comet assay allows a quick and effective evaluation of DNA lesions induced by physical exercise and could be used to monitor athletes avoiding injuries that are more serious.
\end{abstract}

Keywords: Biomarkers/serum. Biomarkers/saliva. Biomarkers/urine. Exercise. Athletes. Athletic injuries. Adenosine deaminase/analysis. DNA.

\section{INTRODUCTION}

Every high-performance sport demands more and more from its athletes because the competitions and training put the athlete's body under constant physiological and psychological stress, often because they happen in a short time, not allowing the musculature to regenerate (Wilcock, Cronin, Hing, 2006). This stress can progress from a benign initial phase to a subclinical injury, which will impair performance and cause wear and tear on the athlete, contributing to the withdrawal of competitions (Lazarim et al., 2009).

Intense physical activity requires a greater energy demand with a consequent increase in the release of AMP, ADP and intra and extracellular ATP to aid in the control

\footnotetext{
*Correspondence: E. O. Chielle. Laboratory of Clinical Biochemistry, Department of Life Sciences, University of West of Santa Catarina, 211 Oiapoc Street, 89900-000, São Miguel do Oeste - SC - Brazil. Tel: +55 (49) 3631-1072. E-mail: eduardochielle@yahoo.com.br
}

of processes such as platelet aggregation, vascular tone control, neurotransmission, membrane permeability, cardiac function and muscle contraction associated with the exercise. (Broberg, Sahlin, 1989; Erlinge, Burnstock, 2008).

Thus, ectonucleotidase enzymes expressed on the surface of several cells, hydrolyze these nucleotides then controlling their levels. This enzymatic complex includes the enzymes E-NTPDase (ectonucleoside triphosphate diphosphohydrolase), E-NPP (ectonucleotide pyrophosphatase/phosphodiesterase), E-5'-nucleotidase and adenosine deaminase (ADA) (Fürstenau et al., 2006). Adenosine can be directly inactivated on the cell surface through the sequential actions of ADA, which catalyzes the irreversible deamination of adenosine and leads to inosine (Blackburn, Kellems, 2005).

In addition, a probable cause of fatigue, muscle damage and inflammation is the occurrence of ruptures of fragile sarcomeres when high forces are applied and are not absorbed and, as a result of interruption of sarcomeres, 
due to heavy/prolonged physical exercise, may occur release of enzymes that are present in the cytoplasm of muscle cells by lesioning the ultrastructure of the fibers and development of an important inflammatory response. (Evans, Meredith, Cannon, 1986; Córdova Martínez, Alvarez-Mon, 1999).

Even ADA being found in small amounts in muscle tissue, it can temporarily increase its serum concentrations as a result of muscle injuries because it is widely distributed in cells of the immune system that participate in the processes of degeneration and regeneration of muscle and surrounding connective tissue after muscle damage (Livi, 1999; Tidball, 2005; Wassmansdorf, 2012).

ADA is a potent inflammatory biomarker that can be determined in both blood and biological fluids as it is widely distributed in human tissues and is associated primarily with CD4 $+\mathrm{T}$ lymphocyte proliferation and performs tight control of extracellular adenosine concentrations (Chielle et al., 2015; Livi, 1999; Zavialov et al., 2010).

Moreover, with increased oxygen consumption $\left(\mathrm{O}_{2}\right)$ due to the practice of intense physical exercises, acute or chronic oxidative lesions may occur in the cells due to the production of reactive oxygen species (ROS) and consequent lipoperoxidation (He et al., 2016). As biomarker of oxidative stress, more specifically lipid peroxidation of the cell membrane, are the substances that react with thiobarbituric acid (TBARS), increasing the levels of this product indicates the existence of oxidative stress in the cells, increasing the risk of cellular rupture and contributing to muscle injury (Alleman et al., 2014).

The responses to the tissue damage may increase in hours and days due to the worsening of the oxidative stress and the infiltration of cells of the immune system that will go to the site of the injury to clean the cellular debris, increasing the inflammatory process (Baroni et al., 2010; Chevion et al., 2003; Souza Jr., Pereira, 2008). Therefore, the search for an early diagnosis of muscle injuries and methods that provide quick results has been an increasing practice in high-performance professional modalities, since the current biochemical monitoring is relatively non-specific and involves some physical and psychological discomfort. The objective of this study was to evaluate TBARS and serum ADA and in other no invasive biological samples such as saliva and urine, as well as evidence that biomarkers of DNA damage may be useful in predicting the onset of overtraining which is a condition of fatigue and drop in physical performance that occurs after intense training and competitions

\section{MATERIAL E METHODS}

\section{Participants}

This essay included 27 male athletes from an American football team from the city of São Miguel do Oeste $-\mathrm{SC}$. The sampling process was performed for convenience and all athletes signed the Free and Informed Consent Form. The Committee of Ethics and research with human beings of the University of the West of Santa Catarina approved the study under the protocol number 1.629.054. For the composition of the samples, inclusion, and exclusion criteria were adopted according to the organization chart 1.

\section{Experimental procedures}

The athletes were submitted to a questionnaire prior to performing physical activity, where information was collected regarding age, weight, height, time of physical activity and systolic and diastolic blood pressure. Athletes' blood pressure was measured before and after physical activity using a manual sphygmomanometer and a Premium brand stethoscope (Accumed-Glicomed, RJ, Brazil). The height of the athletes was measured in centimeters $(\mathrm{cm})$, in a wall stadiometer, Professional ES2020 Sanny® (American Medical do Brasil Ltda, SP, Brazil), and the weight was verified in kilograms $(\mathrm{kg})$, in G-techC scale, model Glass 180, platform type (AccumedGlicomed, RJ, Brazil).

In order to perform the physical training, the athletes were instructed to stay a 3-day period of rest. The group of athletes was submitted to training protocol, as shown in Table I and all training was supervised by the researchers. Further details of the experimental protocol and training program are described in Uchida et al. (2006), Hartman et al. (2007), Hasani-Ranjbar et al. (2012). The performance of the athletes was controlled. These exercises were chosen because they require a great muscular capacity for development. During the exercises, the athletes did not rest, and recovery was active. The air temperature during testing was $21^{\circ} \mathrm{C}$ and relative humidity amounted to $62 \%$, through the Matsuri Temperature and Humidity Meter (Biogênese Comércio de Artigos Médicos Ltda, PR, Brazil).

Samples of blood, saliva, and urine were collected three times: 60 minutes before starting the exercises with the athlete rested (T0), 60 minutes after the physical exercise battery (T1) and 24 hours after the physical exercise battery (T2). All athletes were assessed before and after a single physical exercise session. The blood samples were collected by venipuncture and placed 
TABLE I - Training protocol

\begin{tabular}{|c|c|}
\hline \multicolumn{2}{|c|}{ Warning-up } \\
\hline Exercice & Sequence \\
\hline Stationary bicycle & 2 minutes \\
\hline \multicolumn{2}{|c|}{ Training } \\
\hline Exercice & Sequence \\
\hline Step & 3 sets of 20 repetitions \\
\hline Arm bending bosu & 3 sets of 20 repetitions \\
\hline Forward and curl whit dumble $(10 \mathrm{~kg})$ & 3 sets of 20 repetitions \\
\hline Development with bars and dumbbells $(10 \mathrm{~kg})$ & 3 sets of 20 repetitions \\
\hline Triceps French with washer $(15 \mathrm{~kg})$ & 3 sets of 20 repetitions \\
\hline Swing with kettlebell $(12 \mathrm{~kg})$ & 3 sets of 20 repetitions \\
\hline Burpee & 3 sets of 20 repetitions \\
\hline Isometric squat & 3 sets of 20 repetitions \\
\hline Medicine ball throw $(5 \mathrm{~kg})$ & 3 sets of 20 repetitions \\
\hline Bench triceps & 3 sets of 20 repetitions \\
\hline Speed running & 5 minutes \\
\hline
\end{tabular}

This sequence of exercises was repeated for 60 minutes.

in collection tubes with anticoagulant EDTA and tube without anticoagulant and with separator gel that was left at room temperature for 20 minutes and then centrifuged for 10 minutes at $4000 \mathrm{rpm}$ to obtain the serum.

For saliva collection, athletes were instructed to rinse the mouth with water 3 times; subsequently, a Salivette ${ }^{\circledR}$ was supplied, which consists of a conical container with an absorbent filter. Participants were instructed to remove the filter and place it in the mouth for a period of 3 minutes as recommended by the manufacturer (Salivette Tubes Sarstedt, Nümbrecht, Germany). Afterward, the filter was relocated to the centrifuge container. The samples were frozen at $-20^{\circ} \mathrm{C}$, as recommended by Sereg et al. (2011) until analysis moment.

The urine was collected in a sterile vial, approximately $50 \mathrm{~mL}$. The athletes were instructed to discard the first urine stream and collect midstream directly into the bottle provided. The samples were centrifuged to remove cells, bacteria and crystals, and the supernatant used for laboratory analysis.

In serum, saliva and urine samples, ADA activity was determined by the commercial kit (Ebram Laboratory of Products LTDA ${ }^{\circledR}$ - São Paulo, Brazil), based on the enzymatic deamination of adenosine in inosine by a kinetic form in BIO2000 equipment (BIOPLUS ${ }^{\circledR}$ - São Paulo, Brazil). The values were expressed in U/L. The leukocytes and lymphocytes were analyzed and counted by fluorescence flow cytometry on XS-800i equipment
(Sysmex-Roche Diagnostic USA). Lipid Peroxidation was estimated by the measurement of Thiobarbituric Acid Reactive Substances (TBARS) according to the method established by Lapenna et al. (2001). The reaction product was measured spectrophotometrically at $532 \mathrm{~nm}$ and the results were expressed in $\mathrm{nmol} / \mathrm{L}$. The evaluation of induced damage to the genetic material was performed by comet assay technique in peripheral lymphocytes as described by Singh et al. (1998).

Data were expressed as mean \pm standard deviation. The Kolmogorov-Smirnov test was used to examine the distribution of variables. Data comparisons were performed by one-way analysis of variance (oneway ANOVA), followed by Tukey`s test (parametric variables) or Kruskal-Wallis`s test followed by Dunn's test (nonparametric variables). The value of $p<0.05$ was considered statistically significant. Data were analyzed using Statistica 6.0® software (StatSoft, Tulsa, USA).

\section{RESULTS}

The study population consisted of 27 male volunteers with an average age of $22.5 \pm 4.2$ years old, average weight of $81.9 \pm 13.8 \mathrm{~kg}$, average height of $1.79 \pm 0.6$ meters and physical activity time with an average of $4.0 \pm 2.6$ years. The volunteers' blood pressure did not present a significant difference during the three moments (T0, T1 and T2) as shown in Table II. 
TABLE II - Basic characteristics of the study population

\begin{tabular}{lcccc}
\hline & & T0 & T1 & T2 \\
\hline $\mathrm{N}$ & 27 & & & \\
Gender & Male & & & \\
Age (yaers) & $22.5 \pm 4.2$ & & & \\
Activity time & $4.0 \pm 2.6$ & & & \\
(yaers) & & & & \\
Weight (kg) & $81.9 \pm 13.8$ & & & \\
$\begin{array}{l}\text { Height (m) } \\
\text { Systolic BP }\end{array}$ & $1.79 \pm 0.6$ & & & \\
(mmHg) & & $127 \pm 11$ & $120 \pm 9$ & $123 \pm 13$ \\
$\begin{array}{l}\text { Diastolica BP } \\
\text { (mmHg) }\end{array}$ & & $79 \pm 10$ & $76 \pm 8$ & $76 \pm 9$ \\
\hline
\end{tabular}

Data were expressed as mean and standard deviation. T0: before the exercises were performed; T1: 60 minutes after physical exercises; T2: 24 hours after physical exercises; BP: Blood Pressure.

There was a significant increase in serum ADA activity in $\mathrm{T} 1(\mathrm{p}<0.0001)$ and $\mathrm{T} 2(\mathrm{p}<0.05)$ when compared to $\mathrm{T} 0$, followed by a significant decrease in $\mathrm{T} 2$ when compared to T1 $(\mathrm{p}<0.0001)$. There were no significant changes in ADA activity in saliva. In urine, it was observed a significant increase in ADA activity in T1 $(p<0.0001)$ when compared to $\mathrm{T} 0$, followed by a significant decrease in $\mathrm{T} 2$ when compared to $\mathrm{T} 1(\mathrm{p}<0.0001)$ (Figure 1A, B, C). The Table III show a significant increase of total leukocytes in $\mathrm{T} 1$ when compared to $\mathrm{T} 0$ and a significant decrease in $\mathrm{T} 2$ when compared to $\mathrm{T} 1$. There was also a significant increase in the amount of lymphocytes in T1 and T2 compared to T0. There was a significant increase in serum TBARS 24 hours after physical exercise $(\mathrm{p}<0.05)$. In urine and saliva, it was observed significant increases in $\mathrm{T} 1$ when compared to $\mathrm{T} 0$, while in urine there was a decrease in T2, salivary TBARS remained significantly increased in $\mathrm{T} 2$ when compared to T0 $(\mathrm{p}<0.0001)$. Through the comet assay we observed a significant increase of DNA damage in $\mathrm{T} 1$ and $\mathrm{T} 2$ when compared to $\mathrm{T} 0(\mathrm{p}<0.001)$, evidencing in these times a greater number of lymphocytes with a tail of Grade 3 and 4 (Figure 2A, B).

\section{DISCUSSIONS}

Intense physical activity requires a greater energy demand with a consequent increase in the release of AMP, ADP and intra and extracellular ATP to aid in the control of numerous processes (Broberg, Sahlin, 1989; Erlinge, Burnstock, 2008). ATP and other nucleotides and nucleosides are found in all organ systems where they produce effects both by intracellular and extracellular mechanisms. Intracellular ATP is primarily utilized to drive energy-requiring processes such as active transport, cell motility, and biosynthesis, whereas extracellular ATP is considered a powerful signaling molecule (Yegutkin, 2008). Clear signalling roles for ATP and other nucleotides (ADP, UTP, UDP) have been established in several tissues, including potent neurotransmission in the central nervous system, muscle contractility (Ralevic, Burnstock, 1998; Burnstock, 2007), blood flow distribution and oxygen delivery (Gonzalez-Alonso, Olsen, Saltin, 2002; Sprague, Stephenson, Ellsworth, 2007); immune responses and control of leukocyte trafficking between the blood and tissues (Bours et al., 2006; Salmi, Jalkanen, 2005).

The result of ATP/ADP breakdown via sequential ectonucleotidase reactions is the release of adenosine. Measurements of extracellular adenosine levels (by using enzyme-coupled chemiluminescent or electrochemical methods) demonstrated direct hypoxia-induced releases
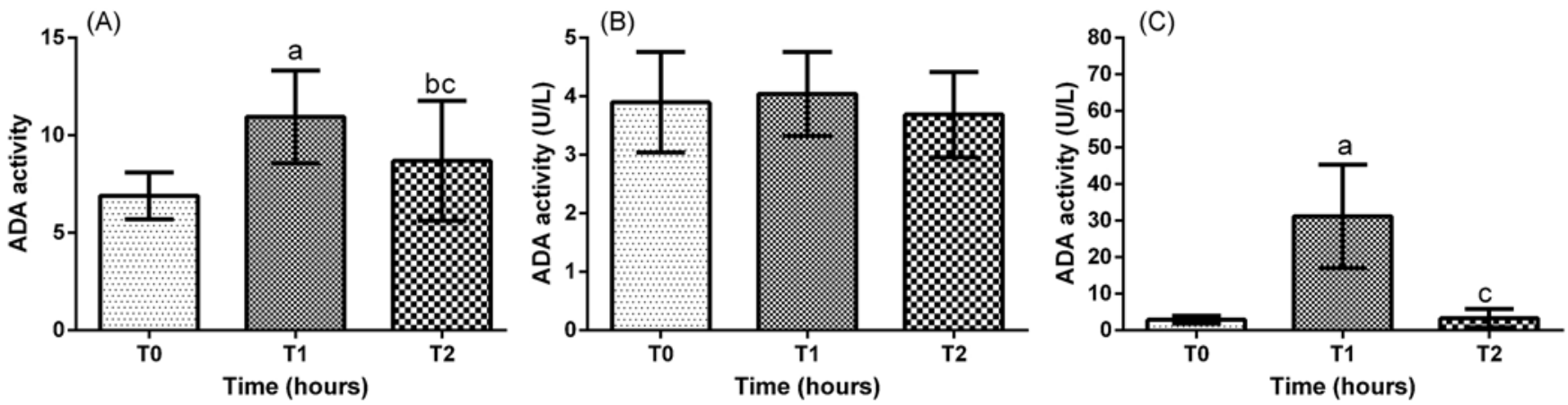

FIGURE 1 - Adenosine deaminase activity. (A) Serum ADA activity; (B) ADA activity in saliva; (C) ADA activity in urine. Data are expressed as means \pm SD or median. The data were processed by analysis of variance (One-Way - ANOVA), followed by the Tukey test or Kruskal-Wallis test, followed by the Dunn test. T0: before the exercises are performed; T1: 60 minutes after physical exercises; T2: 24 hours after physical exercises. ${ }^{\mathrm{a}} \mathrm{p}<0.0001$ when compared to T0. ${ }^{\mathrm{b}} \mathrm{p}<0.05$ when compared to T0. ${ }^{\mathrm{c}} \mathrm{p}<0.0001$ when compared to $\mathrm{T} 1$. 
Evolution of potential biomarkers of acute muscle injury after physical exercise

TABLE III - Quantification of leukocytes, lymphocytes and TBARS in the studied times

\begin{tabular}{|c|c|c|c|}
\hline \multicolumn{4}{|c|}{ Time (hours) } \\
\hline & T0 & $\mathrm{T} 1$ & $\mathrm{~T} 2$ \\
\hline Leukocytes $\left(\mathrm{mm}^{3}\right)$ & $8044 \pm 1536$ & $9596 \pm 1708^{a}$ & $7481 \pm 1398^{b}$ \\
\hline Lymphocytes $\left(\mathrm{mm}^{3}\right)$ & $2275 \pm 159$ & $3399 \pm 237^{\mathrm{a}}$ & $2817 \pm 180^{\mathrm{b}}$ \\
\hline TBARS in serum $(\mathrm{mmol} / \mathrm{L})$ & $309 \pm 118$ & $397 \pm 257^{*}$ & $419 \pm 259^{c}$ \\
\hline TBARS in urine $(\mathrm{mmol} / \mathrm{L})$ & $13.6 \pm 7.3$ & $80.1 \pm 14.3^{\mathrm{a}}$ & $35.5 \pm 10.7^{\mathrm{d}}$ \\
\hline TBARS in saliva (mmol/L) & $19.4 \pm 11.7$ & $26.6 \pm 18.0^{\mathrm{a}}$ & $34.3 \pm 21.6^{\mathrm{ab}}$ \\
\hline
\end{tabular}

Data are expressed as means \pm SD or median. The data were processed by analysis of variance (One-Way - ANOVA), followed by the Tukey test or Kruskal-Wallis test, followed by the Dunn test. T0: before the exercises are performed; T1: 60 minutes after physical exercises; T2: 24 hours after physical exercises. ${ }^{\mathrm{a}} \mathrm{p}<0.001$ when compared to $\mathrm{T} 0 .{ }^{\mathrm{b}} \mathrm{p}<0.01$ when compared to $\mathrm{T} 1{ }^{\mathrm{c}} \mathrm{p}<0.05$ when compared to $\mathrm{T} 0 .{ }^{\mathrm{d}} \mathrm{p}<0.0001$ when compared to $\mathrm{T} 1$.
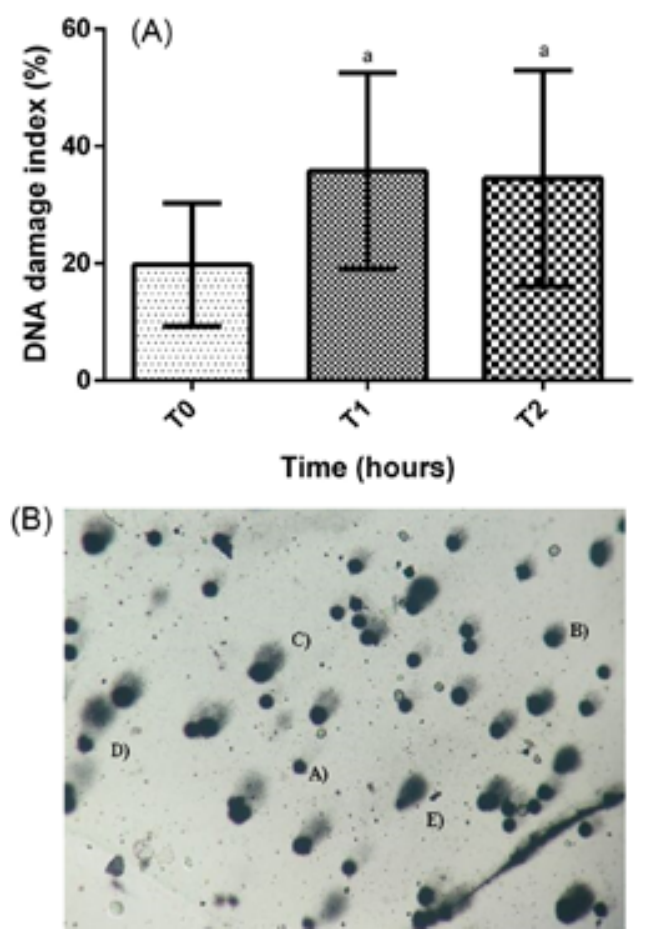

FIGURE 2 - Quantification of DNA damage through the comet assay (A). Photomicrography of comet assays on lymphocytes (B). The data were processed by analysis of variance (OneWay - ANOVA), followed by the Tukey test or Kruskal-Wallis test, followed by the Dunn test. T0: before the exercises are performed; T1: 60 minutes after physical exercises; T2: 24 hours after physical exercises. In A, B, C, D and E, class 0,1 , 2,3 , and 4 comets respectively. The tail size of the comet is proportional to the damage to the genetic material. ${ }^{a} p<0.0001$ when compared to $\mathrm{T} 0$

of micromolar concentrations of this nucleoside from the rat hippocampal slices and cultured rat cortical astrocytes (Martin et al. 2007).

Thus, enzymes expressed in the cytoplasm and on the surface of muscle cells increase their activity to degrade adenosine (Fürstenau et al., 2006). One of the main enzymes that perform this process is ADA, an enzyme that degrades adenosian in iosine (Fürstenau et $a l ., 2006)$. ADA is also an inflammatory enzyme involved in the maturation of cells of the immune system (Chielle et al., 2015; Ferreira et al., 2007; Livi, 1999). The intense physical effort can stimulate a greater production of ATP with subsequent degradation and increase of adenosine, as well as, there is a greater intensity in the inflammatory process which are related to the number of lesions induced by exhaustive physical exercises. In this sense, the results of this study suggest that the increased activity of serum and urinary ADA could be indirect markers of changes in muscle tissue since this enzyme would be concomitantly increased due to the increase of adenosine, its substrate, as well as the inflammatory process installed.

The results showed a significant increase in serum and urinary ADA 60 minutes after intense physical activity, decreasing significantly after 24 hours (Figure $1 \mathrm{~A}$ and $1 \mathrm{C}$ ) when compared with the same individuals rested. Associated with this, an increase in the total count of leukocytes and lymphocytes was observed in Table III, which also increased significantly after 60 minutes of intense physical exercise, decreasing after 24 hours. It is believed that a serious increase in serum and urinary ADA in athletes with high loads of physical training should be an important indicator of muscle changes, such as exhaustion.

Taking the important anti-inflammatory role for adenosine into account, an abundant expression of ectoADA in the tissues may provide an efficient mean for scavenging cell-surrounding adenosine with subsequent sustained activation of dendritic cells and T-lymphocytes during inflammation, even despite the general state of immune suppression (Desrosiers et al, 2007). In addition, lymphoid ecto-ADA, in association with CD26, has been proposed to have a catalytic-independent function as a co- 
stimulatory molecule during $\mathrm{T}$ cell antigen receptor-CD3 complex engagement (Martin et al., 1995), and during the immunological synapse formation (Pacheco et al., $2005)$, thus promoting an augmented $\mathrm{T}$ cell activation and production of proinflammatory cytokines. Compared to lymphocytes, vascular endothelium displays relatively low ecto-ADA activity, however endothelial cell-surface expressions of ADA and its counter-ligand CD26 can be coordinately up-regulated in areas of ongoing inflammation and diminished oxygen supply (Van Linden, Eltzschig, 2007).

It is emphasized that during physical exercises microtraumas and ruptures of the contractile structures and the components of the skeletal muscle cytoskeleton occur, which result in a moderate inflammatory response and release of intracellular proteins into the blood, whose objective is the healing process, recovery and physiological adaptation of the athlete (Nóbrega, 2005; Santos et al., 2004). However, this recovery is not achieved by individuals undergoing intense and prolonged physical exercises, exhaustive and very frequent training (Rogero, Mendes, Tirapegui, 2005), compromising the tissue regeneration process, which results in a greater frequency of injuries and a decrease in athlete performance (Tidball, 2005).

Also the energy demand during physical activity generates an increase in the oxygen supply $\left(\mathrm{O}_{2}\right)$ to the tissues and stimulates the oxidative metabolism, favoring the formation of free radicals (Ji, 2002; Wyatt, Donaldson, Brown, 2013), which are related to the processes of lipid peroxidation, DNA damage and protein oxidation (Finaud, Lac, Filare, 2006). In this study, a significant increase in serum, urinary and salivary TBARS levels was observed (Table III), evidencing an oxidative exacerbation proportionally related to the increase in $\mathrm{O}_{2}$ demand and to the inflammatory process, favoring muscular lesions and the appearance of diseases (Ye et al., 2016). Also, a significant increase in the comet assay (Figure 2) was observed 60 minutes and 24 hours after intense physical exercise. The comet assay is a reproducible and sensitive electrophoretic technique to detect the presence of single-strand breaks (SSB) of DNA, lesions at alkaline and SSB sensitive sites at sites of incomplete excision repair in mammalian cells in vitro and in vivo. Through this technique, it is possible to evaluate DNA damage and repair in proliferating and non-proliferating cells at the individual level (Hartmann et al., 2003).

As shown, ADA activity and serum and urine TBARS levels were significantly higher 60 minutes after intense physical exercise, decreasing 24 hours later, accompanied by a significant increase in leukocytes, lymphocytes and the comet test runoff, showing that these biomarkers could be routinely used to monitor acute muscle injuries and could indicate muscle depletion, oxidative stress and DNA damage in athletes after intense physical exercise, thus helping to prevent cumulative injuries that impair athletes' performance. Some limitations of this study should be recognized as: i the cross-sectional design of the study prevents a demonstrated etiological association between markers, a longitudinal follow-up study is more appropriate for this type of research; ii the study does not address the lifestyle, ethnicity, genetics of volunteers; iii it was not possible to determine the levels of adenosine before and after intense physical exercises.

Nevertheless, this study allowed us to analyze the cellular biochemical alterations that occur in the lesions of the locomotor system in the intense physical exercises, besides highlighting the use of important biological samples, such as saliva and urine, for the biomarkers search of muscular lesions. The results presented here demonstrate that saliva and especially urine can be used for this research and are as accurate as blood to monitor the athlete, standing out with advantages because the collection does not present any discomfort, besides being practical and easy, the samples do not coagulate, in addition to having good stability.

Based on this, these biomarkers could be dosed in non-invasive samples and at different times, especially serum and urinary ADA activity, serum TBARS, urinary and salivary biomarkers which in the future could be used indirectly to evaluate acute muscle injuries, as well as the comet test would allow a rapid and effective evaluation of exercise-induced DNA lesions and could be used to evaluate and monitor athletes in exhaustive training, avoiding more serious injuries.

\section{CONFLICT OF INTEREST}

None

\section{ACKNOWLEDGMENTS}

The work had the financial support of the Article 170 - Constitution of the State of Santa Catarina. The authors wish to thank all the volunteers who participated and the University of Western Santa Catarina (UNOESC), SC, Brazil, for their support in this study.

\section{REFERENCES}

Alleman RJ, Katunga LA, Nelson MA, Brown DA, Anderson EJ. The "Goldilocks Zone" from a redox perspective-adaptive vs. deleterious responses to oxidative stress in striated muscle. Front Physiol. 2014;5(art.358):1-20. [Review]. 
Baroni BM, Junior ECP, Generosi RA, Grosselli G, Censi S, Bertolla F. Efeito da crioterapia de imersão sobre a remoção do lactato sanguíneo após exercício. Rev Bras Cineantropom Desempenho Hum. 2010;12(3):179-85.

Blackburn MR, Kellems RE. Adenosine deaminase deficiency: metabolic basis of immune deficiency and pulmonary inflammation. Adv Immunol. 2005;86:1-41.

Bours MJL, Swennen ELR, Di Virgilio F, Cronstein BN, Dagnelie PC. Adenosine 5'-triphosphate and adenosine as endogenous signaling molecules in immunity and inflammation. Pharmacol Ther. 2006;112(2):358-404.

Broberg S, Sahlin K. Adenine nucleotide degradation in human skeletal muscle during prolonged exercise. J Appl Physiol. 1989;67(1):116-22.

Burnstock G. Physiology and pathophysiology of purinergic neurotransmission, Physiol Rev. 2007;87(2):659-797.

Chevion S; Moran DS; Heled Y; Shani Y; Regev G; Abbou B, et al. Plasma antioxidant status and cell injury after severe physical exercise. Proc Nat Acad Sci. 2003;100(9):5119-23.

Chielle EO, Bonfanti G, De Bona KS, Moresco RN, Moretto MB. Adenosine deaminase, dipeptidyl peptidase-IV activities and lipid peroxidation are increased in the saliva of obese young adult. Clin Chem Lab Med. 2015;53(7):1041-7.

Córdova Martínez A, Alvarez-Mon M. O sistema imunológico (II): importância dos imunomoduladores na recuperação do desportista. Rev Bras Med Esporte. 1999;5(4):159-66.

Desrosiers MD, Cembrola KM, Fakir MJ, Stephens LA, Jama FM, Shameli A, et al. Adenosine deamination sustains dendritic cell activation in inflammation. J Immunol. 2007;179(3):1884 92.

Erlinge D, Burnstock G. P2 receptors in cardiovascular regulation and disease. Purinergic Signal. 2008;4(1):1-20.

Evans WJ, Meredith CN, Cannon JG. Metabolic changes following eccentric exercise in trained and untrained men. J Appl Physiol. 1986;61(1):864-8.

Ferreira CK, Prestes J, Frollini AB, Donatto F, Dias R, Guereschi $\mathrm{MG}$, et al. Influence of short duration acute exercise on the number, viability, functionality and apoptosis of neutrophils in sedentary rats. J Exercise Physiol. 2007;10(6):27-36.
Gonzalez-Alonso J, Olsen DB, Saltin B. Erythrocyte and the regulation of human skeletal muscle blood flow and oxygen delivery: role of circulating ATP. Circ Res. 2002;91(11):104655.

Finaud J, Lac G, Filare E. Oxidative Stress: relationship with exercise and training. Sports Med. 2006;36(4):327-58.

Fürstenau CR, Trentin DS, Barreto-Chaves MLM, Sarkis JJF. Ecto-nucleotide pyrophosphatase/phosphodiesterase as part of a multiple system for nucleotide hydrolysis by platelets from rats: kinetic characterization and biochemical properties. Platelets. 2006;17(2):84-91

Hartman JW, Tang JE, Wilkinson SB, Tarnopolsky MA, Lawrence RL, Fullerton AV, et al. Consumption of fat-free fluid milk after resistance exercise promotes greater lean mass accretion than does consumption of soy or carbohydrate in young, novice, male weightlifters. Am J Clin Nutr. 2007;86(2):373-81.

Hartmann A, Agurell E, Beevers C, Brendler-Schwaab S, Burlinson B, Clay $\mathrm{P}$, et al. Recommendations for conducting the in vivo alkaline Comet assay. Mutagenesis. 2003;18(1):45-51.

Hasani-Ranjbar S, Far ES, Heshmat R, Rajabi H, Kosari H. Time course responses of serum GH, insulin, IGF-1, IGFBP1, and IGFBP3 concentrations after heavy resistance exercise in trained and untrained men. Endocrine. 2012;41(1):144-51.

He F, Li J, Liu Z, Chuang CC, Yang W, Zuo L. Redox mechanism of reactive oxygen species in exercise. Front Physiol. 2016;7(art.486):1-10. [Review].

Ji LL. Exercise-induced modulation of antioxidant defense. Ann N Y Acad Sci. 2002;959(1):82-92.

Lapenna GD, Ciofani SD, Pierdomenico MA, Giamberardino MA, Cuccurullo F. Reaction conditions affecting the relationship between thiobarbituric acid reactivity and lipid peroxides in human plasma. Free Radical Biol Med. 2001;31(3):331-35.

Lazarim FL, Antunes-Neto JM, Silva FO, Nunes LA, Bassini-Cameron A, Cameron LC, et al. The upper values of plasma creatine kinase of professional soccer players during the Brazilian National Champion ship. J Sci Med Sport. 2009;12(1):85-90. 
Livi AL. Adenosina deaminase no diagnóstico de rejeição aguda após transplante renal. [Dissertação de mestrado]. Porto Alegre: Universidade Federal do Rio Grande do Sul, UFRGS, Curso de Medicina; 1999.

Martin ED, Fernandez M, Perea G, Pascual O, Haydon PG, Araque A, et al. Adenosine released by asrocytes contributes to hypoxiainduced modulation of synaptic transmission. Glia. 2007;55(1):36-45.

Martin M, Huguet J, Centelles JJ, Franco R. Expression of ectoadenosine deaminase and CD26 in human T cells triggered by the TCR-CD3 complex. Possible role of adenosine deaminase as costimulatory molecule. J Immunol. 1995;155(10):4630-43.

Nóbrega ACL. The subacute effects of exercise: concept, characteristics, and clinical implications. Exerc Sport Sci Rev. 2005;33(2):84-7.

Pacheco R, Martinez-Navio JM, Lejeune M, Climent N, Oliva $\mathrm{H}$, Gatell JM, et al. CD26, adenosine deaminase, and adenosine receptors mediate costimulatory signals in the immunological synapse. Proc Natl Acad Sci U S A. 2005;102(27):9583-8.

Ralevic V, Burnstock G. Receptors for purines and pyrimidines. Pharmacol Rev. 1998;50(3):413-92

Rogero MM, Mendes RR, Tirapegui, J. Aspectos neuroendócrinos e nutricionais em atletas com overtraining. Arq Bras Endocrinol Metabol. 2005;49(3):359-68.

Salmi M, Jalkanen S. Cell-surface enzymes in control of leukocyte trafficking. Nat Rev Immunol. 2005;5(10):760-71.

Santos RV, Bassit RA, Caperuto EC, Costa Rosa LF. The effect of creatine supplementation up on inflamatory and muscle soreness markers after a $30 \mathrm{~km}$ race. Life Sci. 2004;75(16):191724.

Sereg M, Toke J, Patócs A, Varga I, Igaz P, Szücs N, et al. Diagnostic performance of salivary cortisol and serum osteocalcin measurements in patients with overt and subclinical Cushing's syndrome. Steroids. 2011;76(1/2):38-42.

Singh NP, Mccoy MT, Tice RR, Schneider EL. A simple technique for quantification of low levels of DNA damage in individual cells. Exp Cell Research. 1998; 175 (1): 184-91.

Souza Jr. TP, Pereira B. Exercício físico intenso como próoxidante: mecanismos de indução de estresse oxidativo e consequências. Rev Bras Ciênc Mov. 2008; 16(3):1-26.
Sprague RS, Stephenson AH, Ellsworth ML. Red not dead: signaling in and from erythrocytes. Trends Endocrinol Metab. 2007;18(9):350-5.

Tidball JG. Inflamatory processes in muscle injury and repair Am J Physiol Regul Integr Comp Physiol. 2005;288(2):R34553.

Uchida MC, Aoki MS, Navarro F, Tessutti VD, Bacurau RFP. Efeito de diferentes protocolos de treinamento de força sobre parâmetros morfofuncionais, hormonais e imunológicos. Rev Bras Med Esporte. 2006;12(1):21-6.

Van Linden A, Eltzschig HK. Role of pulmonary adenosine during hypoxia: extracellular generation, signaling and metabolism by surface adenosine deaminase/CD26. Expert Opin Biol Ther. 2007;7(9):1437-47.

Wassmansdorf R. Efeitos da crioterapia de imersão sobre indicadores bioquímicos, neurais e motores de desempenho e a reativação parassimpática em atletas de futebol. [Dissertação de mestrado]. Curitiba: Universidade Federal do Paraná, Curso de Educação Física; 2012.

Wilcock IM, Cronin JB, Hing WA. Physiological response to water immersion: a method for sport recovery? Sports Med. 2006;36(9):747-65.

Wyatt FB, Donaldson A, Brown E. The overtraining syndrome: a meta-analytic review. J Exercise Physiol. 2013;16(2):12-23.

Ye B, Hou N, Xiao L, Xu Y, Xu H, Li F. Dynamic monitoring of oxidative DNA double-strand break and repair in cardiomyocytes. Cardiovasc Pathol. 2016;25(2):93-100.

Yegutkin GG. Nucleotide- and nucleoside-converting ectoenzymes: important modulators of purinergic signalling cascade. Biochim Biophys Acta. 2008;1783(5):673-94.

Zavialov AV, Gracia E, Glaichenhaus N, Franco R, Zavialov AV, Lauvau G. Human adenosine deaminase 2 induces differentiation of monocytes into macrophages and stimulates proliferation of T helper cells and macrophages. J Leukoc Biol. 2010;88(2):279-90.

Received for publication on $29^{\text {th }}$ September 2017 Accepted for publication on $02^{\text {nd }}$ May 2018 